\title{
Punching shear in concrete reinforced flat slabs with steel fibers and shear reinforcement
}

\section{Punção em lajes lisas de concreto armado com fibras de aço e armadura de cisalhamento}
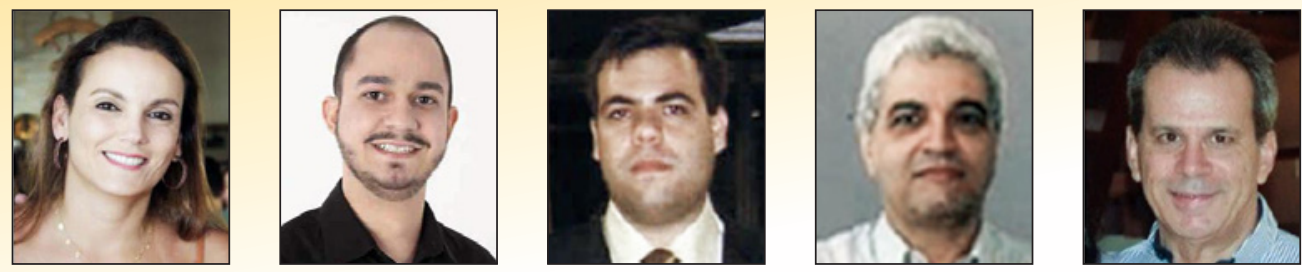

T. H. MUSSE a tais.musse@gmail.com

E. A. P. LIBERATI b, elyson@utfpr.edu.br

L. M. TRAUTWEIN leandromt@gmail.com

R. B. GOMES d rbggomes@gmail.com

G. N. GUIMARÃES d rgilson.natal@gmail.com

\begin{abstract}
Steel fibers in reinforced concrete increase the performance of slab-column connection once they increase ductility and energy absorption capacity of the concrete. The use of fibers in flat slabs may increase strength and change the mode of failure. The objective of this work is to present an experimental evaluation of punching shear strength of reinforced concrete flat slab with steel fibers and punching shear reinforcement. Eight square slabs, size $1800 \mathrm{~mm}$ by $1800 \mathrm{~mm}$ by $130 \mathrm{~mm}$, were loaded until failure by punching shear around the column. The models were divided in two groups, depending on the type of the concrete used (with or without steel fibers). The steel fiber volume used in the slabs of second group was of $0.9 \%$. Each group was composed of four slabs: one without shear reinforcement and three with shear reinforcement (studs) distributed radially around the column. The use of steel fibers increased the ultimate strength of all flat slabs. In one of the slabs, the association of steel fibers with shear reinforcement changed the failure surface from outside to inside the punching shear reinforcement region.
\end{abstract}

Keywords: reinforced concrete, flat slabs, punching, shear, fibers.

\section{Resumo}

A inclusão de fibras de aço em sistemas de ligações laje-pilar se torna interessante uma vez que as fibras podem melhorar a ductilidade e capacidade de absorção de energia do concreto. O uso das fibras melhora o desempenho dessas lajes, seja pelo aumento da resistência, seja pela modificação do modo de ruptura. O objetivo deste trabalho é apresentar uma análise experimental para avaliação do efeito da punção em lajes lisas de concreto armado com adição de fibras de aço e armaduras de cisalhamento. Para isso, oito lajes quadradas, $1800 \mathrm{~mm}$ por $1800 \mathrm{~mm}$ por $130 \mathrm{~mm}$, foram carregadas axialmente até a ruptura. Os modelos foram divididos em dois grupos, dependendo do tipo de concreto utilizado (com ou sem fibras de acco). O volume de fibra de aço utilizado nas lajes do segundo grupo foi de $0,9 \%$. Cada grupo foi composto por quatro modelos: um sem armadura de cisalhamento e três com armadura de cisalhamento (studs) distribuídos radialmente em torno do pilar. O uso de fibras de aço aumentou a capacidade resistente das lajes lisas em todos os modelos testados. Em um dos modelos, a associação de fibras de aço com armadura de cisalhamento alterou o modo de ruptura da laje de externo às armaduras de cisalhamento para ruptura interna à região armada.

Palavras-chave: concreto armado, lajes lisas, punção, fibras.

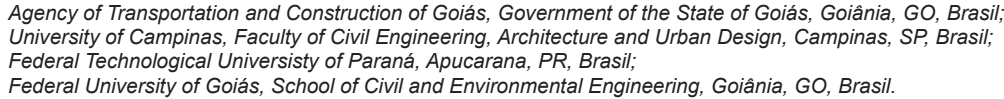




\section{Introduction}

Flat slabs, also called flat plates, are structurally reinforced or prestressed concrete slabs supported directly by the columns, without the existence of beams (NBR 6118:2014). Their use has been common for decades, mostly due to the simplicity of the structural system, construction costs and execution time, and flexibility of construction space (Albuquerque, 2010; Nguyen-Minh et al. 2011). According to Lima Neto (2012), the main disadvantages of flat slabs are: greater vertical displacements, larger moments at the column connection, less stability due to horizontal forces and possible failure by punching shear at the slab-column connection.

Punching shear failure may occur in thin slabs under concentrated loads leading to high shear stresses in small regions around the columns Albuquerque, 2010; Nguyen-Minh et al. 2011). According to Trautwein (2011), a punching shear failure may lead to progressive collapse if the structure does not have enough load redistribution capacity.

Several variables influence punching shear in flat slab design such as the use of high strength concrete, column geometry at the slab interface, slab depth and use of reinforcement to improve shear strength as shown in previous research done by Gomes and Regan (1999), Borges, Melo and Gomes (2013) and Silva et al. (2017).

According to Maghsoudi and Sharifi (2009), self-compacting concrete (SSC) improves the punching shear strength of slabs although they present less ductility then conventional concrete and a smoother failure surface thus decreasing the contribution of aggregate interlock. Choi et al. (2007) state it is evident that shear reinforcement contributes to increase punching shear strength. However, the authors observe that the type and distribution of shear reinforcement around the column can make placement of flexural reinforcement difficult.

Recently the use of fibers to increase shear strength of reinforced concrete has been widely studied as shown in research done by Choi et al. (2007), Hanai and Holanda (2008), Cheng and ParraMontesinos (2010), Maya et al. (2012) and Gouveia et al. (2014).

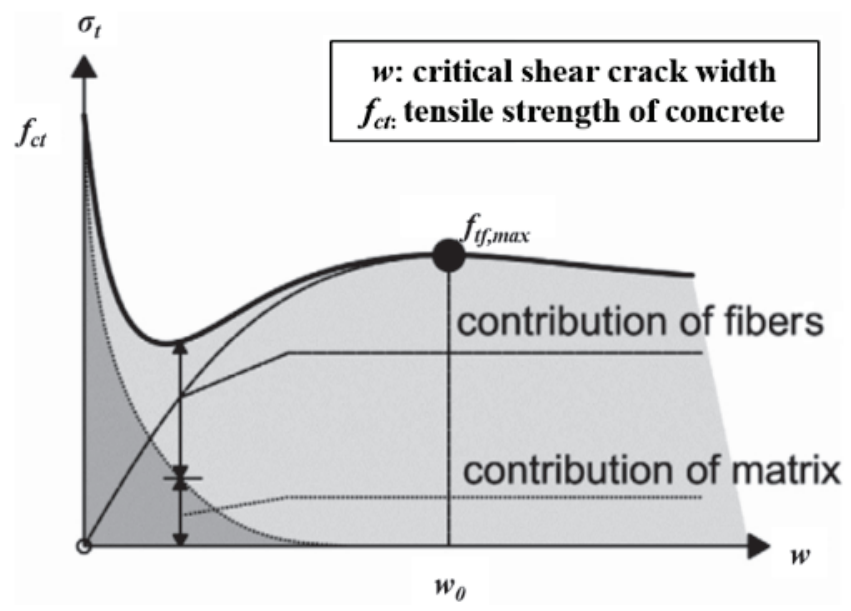

Figure 1

Post cracking behaviour of fiber reinforced concrete - matrix and fiber contributions
These studies have concluded that the use of steel fibers in slab-column connections significantly improves ductility and energy absorption capacity of the concrete. Such an increase in ductility comes from the tie action of fibers after cracking of the concrete matrix (Figure 1). The use of fibers may increase the performance of such slabs by increasing their strength or by changing to a more ductile mode of failure. Also, fibers reduce stress concentrations at ends of flexure and shear cracks, controlling crack propagation, according to Figueiredo (2011) and Moraes Neto, Barros and Melo (2013).

The objective of this article is to evaluate the possibility of increasing punching shear strength of reinforced concrete flat slabs with the use of studs as shear reinforcement and of steel fiber reinforced concrete. Tests were done on reinforced concrete flat slabs subjected to concentric column loading.

\section{Materials and experimental program}

This work covers punching shear in reinforced concrete building with flat slabs subjected to symmetrical vertical loading without moment transfer at the slab-column connection. The slab and the experimental setup simulated a negative moment region limited by the slab's inflection points with a length of approximately two fifths of the total span $(4500 \mathrm{~mm})$ as shown in Figure 2.

Eight square reinforced concrete slabs were tested until failure. The slabs were $1800 \mathrm{~mm}$ long with a thickness of $130 \mathrm{~mm}$. The most important variables used were: existence and amount of shear reinforcement, and use of reinforced concrete with the addition of steel fibers. Other parameters such as loading position, concrete compressive strength and slab size remained unchanged.

All slab testing was done at the Structures Laboratory of the School of Civil Engineering of the Federal University of Goiás. Material property tests were done at the laboratories of Carlos Campos Consulting and the Concrete Laboratory of the Center of Engineering Technology of Furnas Centrais Elétricas S.A. All these facilities are located at the metropolitan area of Goiânia, Goiás.

\subsection{Slab characteristics}

The slabs were divided into two groups: Group 1 - slabs cast with conventional concrete (named L1, L2, L3 and L4) and

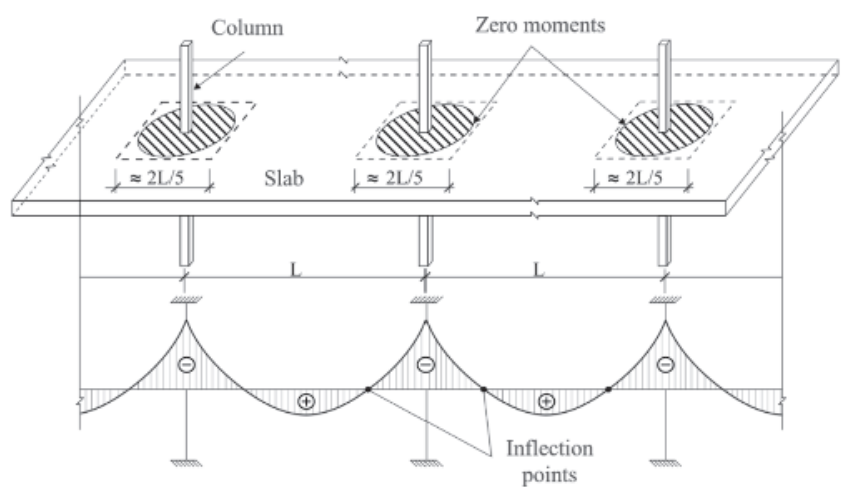

Figure 2

Idealized interior panel characterizing

the situation studied 
Table 1

Slab characteristics

\begin{tabular}{|c|c|c|c|c|c|c|}
\hline \multirow[b]{2}{*}{ Group } & \multirow[b]{2}{*}{ Slab } & \multirow[b]{2}{*}{ Fibers } & \multicolumn{4}{|c|}{ Shear reinforcement } \\
\hline & & & $\begin{array}{c}\varphi \\
(\mathrm{mm})\end{array}$ & $\begin{array}{c}\text { \# of } \\
\text { layers }\end{array}$ & $\begin{array}{c}\mathrm{S}_{0} \\
(\mathrm{~mm})\end{array}$ & $\begin{array}{c}\mathrm{S}^{\prime} \\
(\mathrm{mm})\end{array}$ \\
\hline \multirow{4}{*}{1} & L1 & \multirow{4}{*}{ No } & - & - & - & - \\
\hline & L2 & & 10 & 3 & 42 & 42 \\
\hline & L3 & & 10 & 5 & 42 & 63 \\
\hline & L4 & & 5 & 7 & 42 & 42 \\
\hline \multirow{4}{*}{2} & LF1 & \multirow{4}{*}{ Yes } & - & - & - & - \\
\hline & LF2 & & 10 & 3 & 42 & 42 \\
\hline & LF3 & & 10 & 5 & 42 & 63 \\
\hline & LF4 & & 5 & 7 & 42 & 42 \\
\hline
\end{tabular}

Group 2 - slabs cast concrete with steel fibers (named LF1, LF2, LF3 and LF4). The steel fibers had a circular cross section and hooks at the ends for anchorage. The fiber percentage used was $0.9 \%$, which is equivalent to $70.6 \mathrm{~kg}$ of fibers per cubic meter of concrete.

To achieve a desired punching shear failure, a high flexural horizontal steel ratio of $1.38 \%$ was used. The presence, quantity and spacing of shear reinforcement (steel studs) varied for each slab. All studs were radially distributed around the column.

The first two slabs in each group (slabs L1 and LF1) were taken

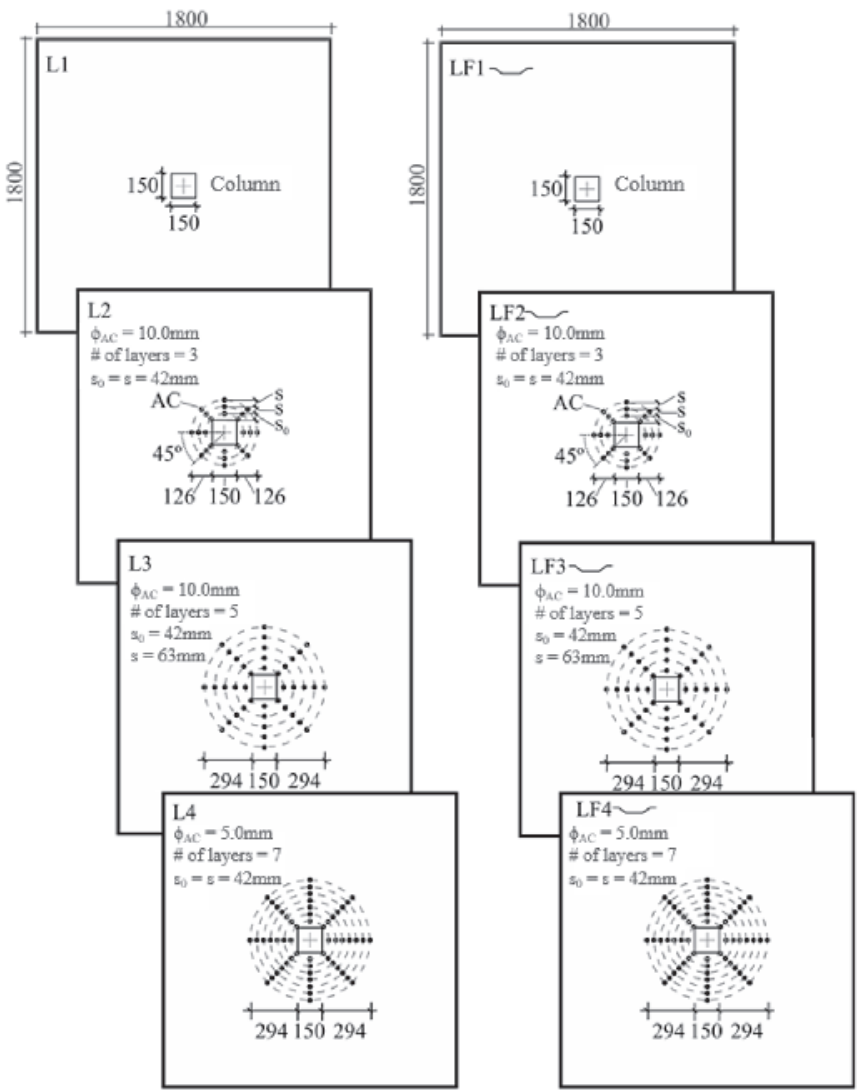

Figure 3

Slab characteristics (units in $\mathrm{mm}$ ) as reference slabs and had no shear reinforcement. Three equally spaced layers of shear studs (diameter of $10 \mathrm{~mm}$ ) were placed at every $42 \mathrm{~mm}$ for slabs L2 and LF2. The same diameter studs were used in slabs L3 and LF3, but the number of layers was increased to five and spacing was also increased to $63 \mathrm{~mm}$. A $42 \mathrm{~mm}$ spacing stud distribution was used in slabs L4 and LF4 but they reached the same outside radius as the studs in slabs L3 and LF3 so two extra layers were used. Stud diameter was reduced to $5 \mathrm{~mm}$ in slabs L4 and LF4. These slab parameters are shown in Table 1 and in Figure 3 for all slabs.

\subsection{Test setup}

The load was applied upward with a $1500 \mathrm{kN}$ capacity hydraulic jack (Yellow Power model) placed at the bottom of the slab's centre. The slabs were tied to the strong floor through a set of 4 steel beams placed at each slab edge and 4 steel rods as shown in Figure 4. Eight small $120 \mathrm{~mm}$ by $200 \mathrm{~mm}$ by $25 \mathrm{~mm}$ thick steel plates were placed between the slab's top surface and the steel beams, at a radial distance of $825 \mathrm{~mm}$ from the slab's center.

This setup was used to obtain a similar force distribution of an interior column without moment transfer. The eight small plates served as the slab's reaction points. Figure 4 shows the drawings and photographs of the setup ready for testing.

\subsection{Details on models tested}

All slabs had the same flexural reinforcement as described below and detailed in Figure 5.

- Top reinforcement: nineteen $12.5 \mathrm{~mm}$ diameter rebars both ways (yield strength $\mathrm{f}_{\mathrm{y}}$ of $508 \mathrm{MPa}$ e yielding strain $\mathrm{e}_{\mathrm{y}}$ of 2.83 $\mathrm{mm} / \mathrm{m})$;

- Bottom reinforcement: eleven $6.3 \mathrm{~mm}$ diameter rebars both ways (yield strength $f_{y}$ of $558 \mathrm{MPa}$ e yielding strain $e_{y}$ of 3.06 $\mathrm{mm} / \mathrm{m})$;

- To assure anchorage of the top flexural reinforcement, nineteen $6.3 \mathrm{~mm}$ diameter "U" shaped horizontal hooks were added at each side of the slab (yield strength $\mathrm{f}_{\mathrm{y}}$ of $558 \mathrm{MPa}$ e yielding strain $e_{y}$ of $3.06 \mathrm{~mm} / \mathrm{m}$ ).

Only slabs L 1 and LF1 did not have shear reinforcement. All other slabs had stud type shear reinforcement built with steel rebars welded to $40 \mathrm{~mm}$ wide by $10 \mathrm{~mm}$ thick steel plates. Studs were $10 \mathrm{~mm}$ diameter rebars in slabs L2, L3, LF2 and LF3, with yield strength $\mathrm{f}_{\mathrm{y}}$ of $839 \mathrm{MPa}$ and yield strain $\mathrm{e}_{\mathrm{y}}$ of $4.18 \mathrm{~mm} / \mathrm{m}$; and $5 \mathrm{~mm}$ diameter rebars in slabs L4 and LF4, with yield strength $\mathrm{f}_{\mathrm{y}}=624$ $\mathrm{MPa}$ and yield strain $\mathrm{e}_{\mathrm{y}}$ of $3.41 \mathrm{~mm} / \mathrm{m}$. Studs were manually welded to the steel plates using a $3.5 \mathrm{~mm}$ diameter ESAB electrode.

Figure 6 shows the studs and their sizes. The size of the stud's steel plates was chosen such that anchorage of the studs was guaranteed during testing. The top flexural rebars were placed below the top steel plates and bottom flexural rebars were placed above the bottom steel plates as shown in Figure 7. This figure also shows all vertical dimensions used for steel positioning.

Figure 8 shows the shear reinforcement distribution, the distance $S_{0}$ from the column face to the innermost stud placed at a line perpendicular to the column face, stud spacing $S$ ' and the angle a between lines of studs. Shear reinforcement and flexural 

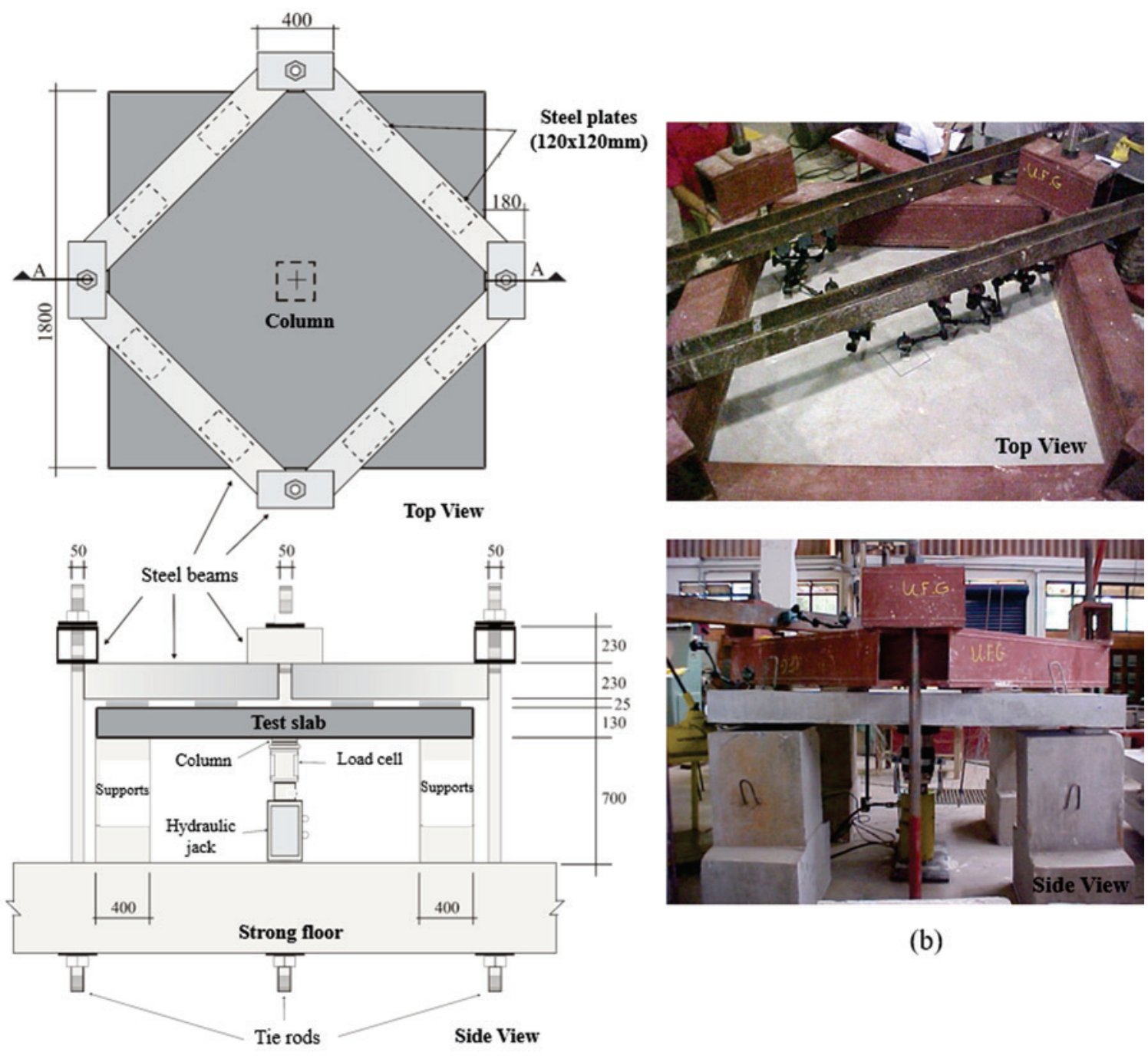

(b)

(a)

\section{Figure 4}

Test setup - (a) top and side view; (b) photo of setup (units in $\mathrm{mm}$ )

reinforcement of slabs L2 and LF2 is shown in the photo of Figure 9. The distance $S_{0}$ was $42 \mathrm{~mm}$ in all slabs. Stud spacing $S^{\prime}$ was 42 $\mathrm{mm}$ for slabs L2, LF2, L4 and LF4, and $63 \mathrm{~mm}$ for slabs L3 e LF3. Radial distribution of the shear reinforcement was done in 3 layers in slabs L2 and LF2, 5 layers in slabs L3 and LF3 and seven layers in slabs L4 and LF4. All slabs had eight lines of reinforcement placed radially equidistant, forming an angle of $45^{\circ}$ between them. Slabs were designed for a punching shear failure but with different failure surfaces. Failures surface crossed the shear reinforce-

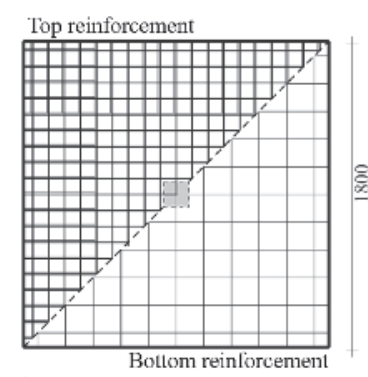

\section{N1 $19 \phi 12.5 \mathrm{~mm}(3) 94 \mathrm{~mm}$ both ways 1750}

N2-11 $\$ 6.3 \mathrm{~mm} @ 163 \mathrm{~mm}$ both ways

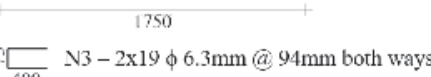

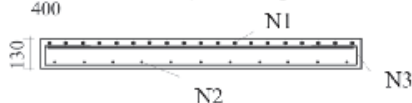

1800

Figure 5

Slab flexural reinforcement (units in $\mathrm{mm}$ ) ment for slabs L4 and LF4 and failure surfaces were outside the shear reinforcement region for slabs L2, LF2, L3 e LF3. Hence, the

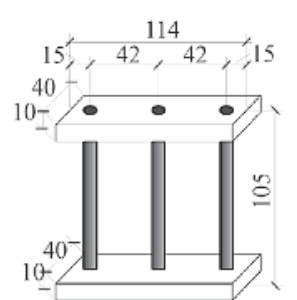

Slabs L2 and LF2 $(\phi 10 \mathrm{~mm})$

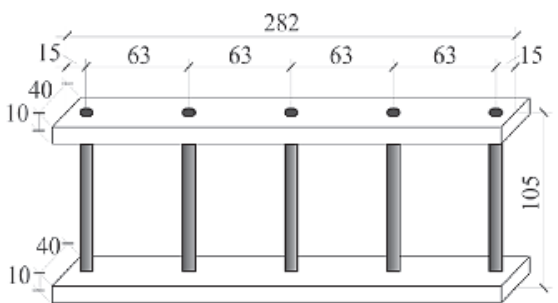

Slabs L3 and LF3 ( $\phi 10 \mathrm{~mm})$ 282

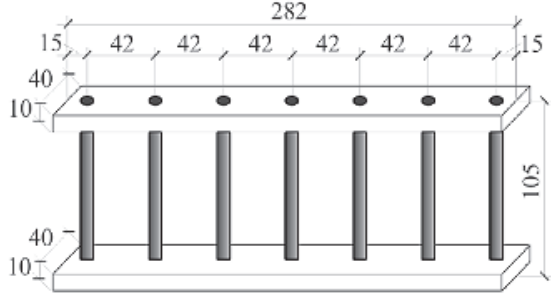

Slabs L4 and LF5 ( $\phi 5 \mathrm{~mm})$
Figure 6

Shear reinforcement (units in $\mathrm{mm}$ ) 


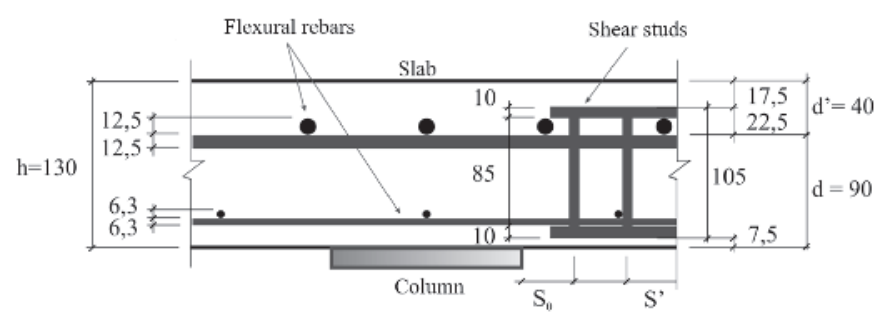

\section{Figure 7}

Positions of shear and flexural reinforment (units in $\mathrm{mm}$ )

distance from the column face to the outermost stud is the same (294 mm) for slabs L3, LF3, L4 and LF4 but the number of layers (five for slabs L3 and LF3, and seven for slabs L4 e LF4), stud spacing $(63 \mathrm{~mm}$ for slabs L3 and LF3, and $42 \mathrm{~mm}$ for slabs L4 and
LF4) and stud diameter (10 $\mathrm{mm}$ for slabs L3 and LF3, and $5 \mathrm{~mm}$ for slabs L4 e LF4) were different.

DRAMIX RC 80/60 BN steel fibers manufactured by Bekaert were used. Fibers were $60 \mathrm{~mm}$ long, had a nominal diameter of 0.75 $\mathrm{mm}$ and a size factor (diameter/length ratio) of 80 . These fibers had hooks at both ends and were glued to each other but fell apart during concrete mixing due to the presence of water.

Concrete mix design aimed for a 28-day compressive strength of $35 \mathrm{MPa}$. Concrete was mixed and delivered by a local concrete supplier called Realmix Concrete S.A. Both concrete with and without steel fibers had the same mix design. Fibers were added after mixing the aggregates and before mixing all the water and cement. Superplasticizer was added to the concrete minutes before initiating casting.

Casting of the eight slabs was divided into the two groups. First, the four slabs of conventional concrete were cast (named Goup 1 ) and then the other four slabs (named Group 2) were cast with

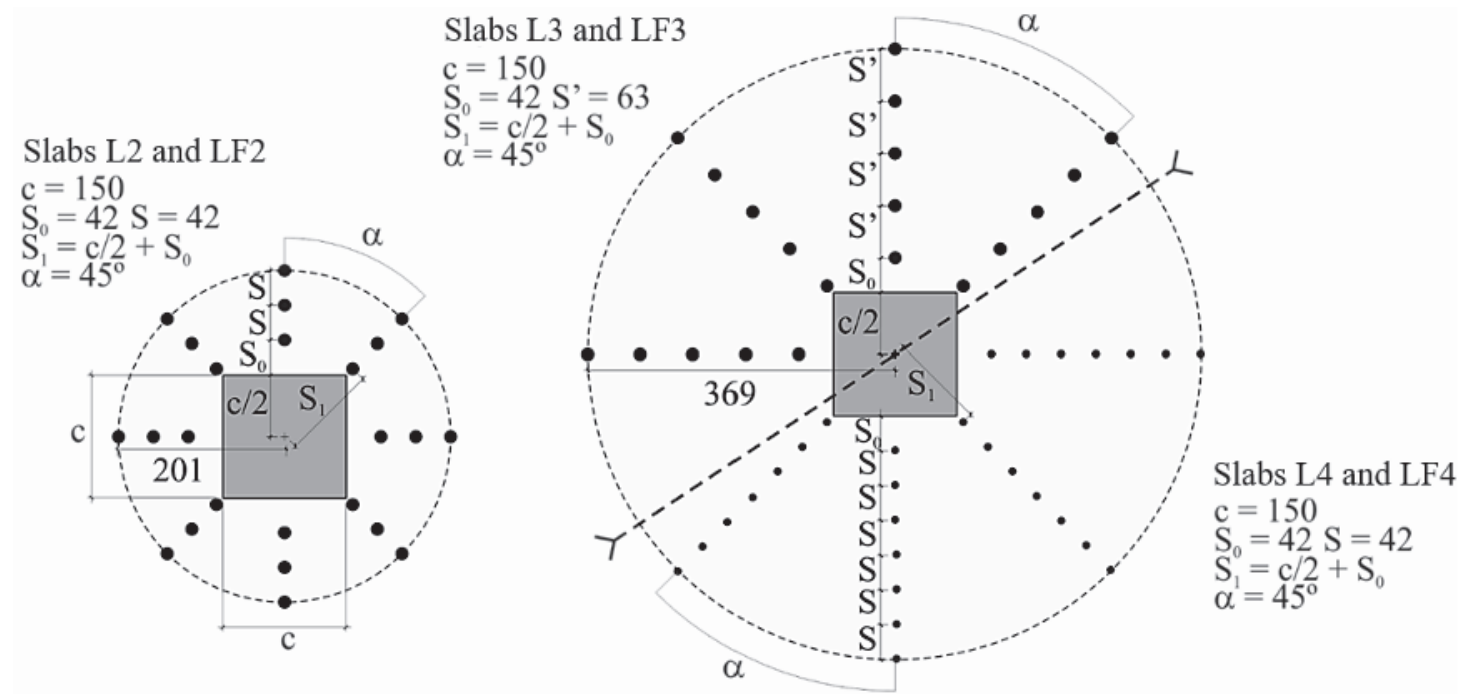

Figure 8

Distribution of shear reinforcement (units in $\mathrm{mm}$ )
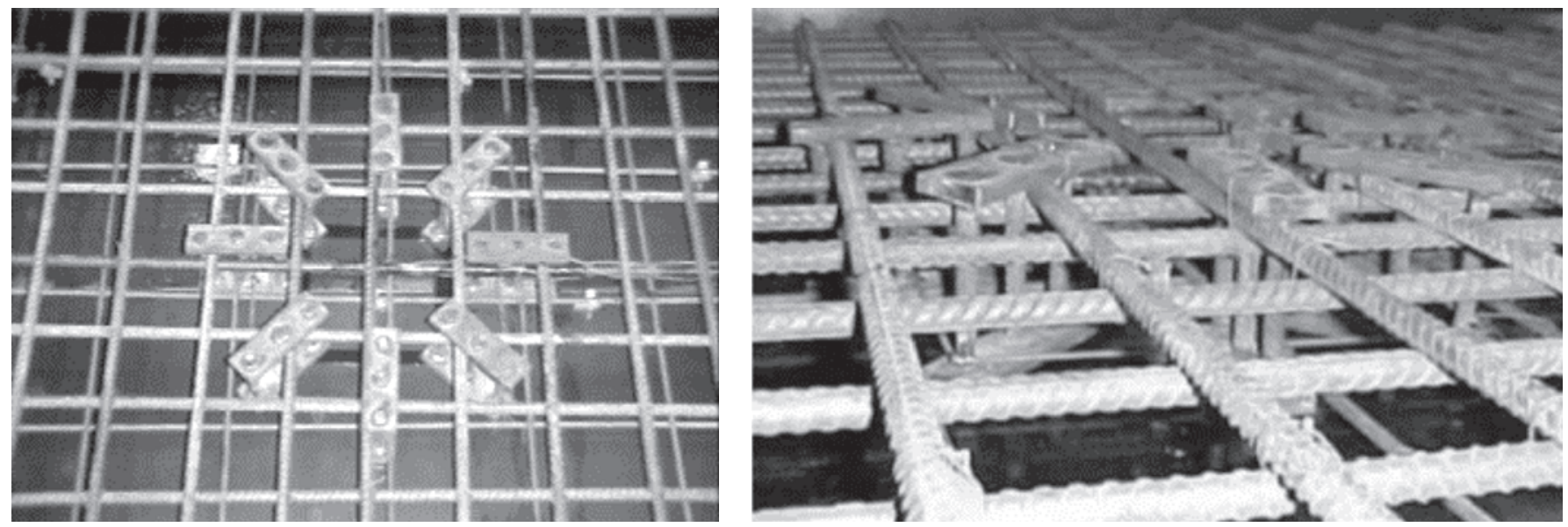

Figure 9

Shear and flexural reinforcement in slabs L2 and LF2 
Table 2

Composition by $\mathrm{m}^{3}$ of concrete (provided by Realmix Concrete S.A.)

\begin{tabular}{|c|c|}
\hline Materials & Quantity per $\mathrm{m}^{3}$ \\
\hline Aggregate $\mathrm{n}^{\circ} 0(\mathrm{~kg})$ & 1048 \\
\hline Aggregate $\mathrm{n}^{\circ} 1(\mathrm{~kg})$ & 3468 \\
\hline Natural sand $(\mathrm{kg})$ & 415 \\
\hline Artificial sand (kg) & 637 \\
\hline Cement Goiás CP II F 32 (kg) & 440 \\
\hline CSF Silmix - Camargo Corrêa (kg) & 41.8 \\
\hline Retarding admixture $390 \mathrm{MB}-\mathrm{MBT}(\mathrm{I})$ & 2.64 \\
\hline Water (I) & 172 \\
\hline Steel fiber $(\mathrm{kg})$ & 70.6 \\
\hline Ratio water/ (cement + CSF) & 0.36 \\
\hline \multicolumn{2}{|l|}{ CFS = Condensed silica fume } \\
\hline
\end{tabular}

fibers in the concrete. The concrete mix proportions are reported in Table 2.

The mechanical properties of concrete (compressive strength, splitting tensilest and modulus of elasticity) were conducted using $150 \times 300 \mathrm{~mm}$ cylindrical specimens. These properties can be seen in Table 3.

\section{Results and discussion}

\subsection{Ultimate loads and mode of failure}

All slabs failed in punching shear. For flat slabs without shear reinforcement and fibers, with a flexural reinforcement ratio around $1.2 \%$, the flexural strength is approximately double that of the punching shear strength. All slabs with shear reinforcement had a failure surface outside the shear reinforced region except for slab LF4. Slab LF4 from Group 2 had a different failure surface than its counterpart L4 from Group 1. The failure surface started at one of the column faces, at the bottom surface of the slab, and crossed the two innermost layers of shear reinforcement before reaching the top surface of the slab. Thus, the presence of fibers in slab LF4 modified the failure surface from outside the shear reinforced region to inside the shear re- inforced region. Figure 10 shows the cross section of the slab indicating the failure surface.

The slabs were loaded in steps of $50 \mathrm{kN}$ until failure. Ultimate load was the maximum load obtained from the load cell recorder. The slab's self-weight and the steel beams are not considered in the ultimate load. Table 3 presents the most important slab characteristics and compares their ultimate loads. Concrete compressive strength in slabs without fibers was $42 \mathrm{MPa}$ and compressive strength for slabs with fibers was $36 \mathrm{MPa}$ on testing day. Concrete tensile strength ranged from 3.7 MPa to 4.0 MPa. To evaluate fiber influence on punching shear, ultimate loads from slabs with fibers (loads $\mathrm{V}_{\mathrm{uLFi}}$ ) were compared to ultimate loads from similar slabs without fibers (loads $\mathrm{V}_{\mathrm{uLi}}$ ), as for example, slabs LF1 and L1 (ratio $\mathrm{V}_{\mathrm{uLF} 1} / \mathrm{V}_{\mathrm{uL} 1}$ ). The ultimate loads from each slab were compared to the group's reference slab without shear reinforcement (loads $V_{\mathrm{uL} 1}$ and $\mathrm{V}_{\mathrm{uLF} 1}$ for reference slabs L1 and LF1, respectively). These comparisons are shown in Table 3 as ratios $\mathrm{V}_{\mathrm{uL}} / \mathrm{V}_{\mathrm{uL} 1}$ for Group 1 and as ratios $\mathrm{V}_{\mathrm{uLFi}} / \mathrm{V}_{\mathrm{uLF} 1}$ for Group2.

Assuming all slabs without fibers had the same compressive strength and practically the same effective depth (no more than a $2 \%$ difference), results in Table 3 show slabs L2, L3 and L4 had ultimate loads about $50 \%$ higher than their reference slab L1 as shown by the ratio $\mathrm{V}_{\mathrm{uL}} / \mathrm{V}_{\mathrm{uL} 1}$. Slabs with fibers and shear reinforcement (Group 2) had ultimate loads averaging 33\% higher than their reference slab LF1 as expressed by the ratio $\mathrm{V}_{\mathrm{uLF}} / \mathrm{Vu}_{\mathrm{LF} 1}$. In this case, effective depth varied about $7 \%$.

Evidently, shear reinforcement increased punching shear strength in all slabs. This increase was higher in slabs without fibers. For example, ultimate loads were $49 \%$ higher for slab L2 compared to slab $\mathrm{L} 1$; both slabs without fibers. But ultimate loads were $33 \%$ higher for slab LF2 compared to slab LF1; both slabs with fibers. Also, slab L3 had an ultimate load $53 \%$ higher than the ultimate load of slab L1 and $14 \%$ higher than when similar slabs with fibers LF3 and LF1 are compared. This difference was highest $(28 \%)$ when slabs $L 4$ and LF4 are compared to their respective reference slabs.

Slabs L3 and L4 had different layers of shear reinforcement, different stud spacing and diameter, but the perimeter of the shear reinforcement region was the same with a radius of $369 \mathrm{~mm}$. Both slabs had practically the same ultimate loads ( $472 \mathrm{kN}$ for slab L3 and $467 \mathrm{kN}$ for slab L4) and the failure surface was external to the shear reinforcement in both cases.

Table 3

Main slab characteristics and ultimate load comparisons

\begin{tabular}{|c|c|c|c|c|c|c|c|c|c|c|}
\hline Group & Slab & $\begin{array}{c}\mathrm{d} \\
( \pm 2 \mathrm{~mm})\end{array}$ & $\begin{array}{c}f_{c} \\
\left(M P{ }^{\prime} a\right)\end{array}$ & $\begin{array}{c}f_{t} \\
(M P a)\end{array}$ & $\begin{array}{c}E_{c} \\
(G P a)\end{array}$ & $\begin{array}{c}\text { Shear } \\
\text { reinforcement }\end{array}$ & 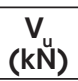 & $\mathrm{V}_{\mathrm{uLFi}} / \mathrm{V}_{\mathrm{uLi}}$ & $\mathrm{V}_{\mathrm{uLi}} / \mathrm{V}_{\mathrm{uLI}}$ & $\mathrm{V}_{\mathrm{uLFi}} / \mathrm{V}_{\mathrm{uLF}}$ \\
\hline \multirow{4}{*}{$\begin{array}{c}1 \\
f_{c}= \\
42 \mathrm{MPa}\end{array}$} & L1 & 91 & 41.7 & 3.7 & 25.3 & - & 309 & 1.26 & 1.00 & - \\
\hline & L2 & 89 & 42.0 & 3.8 & 25.5 & 3 p10mm & 460 & 1.12 & 1.49 & - \\
\hline & L3 & 88 & 42.2 & 3.8 & 25.8 & $5 \varphi 10 \mathrm{~mm}$ & 472 & 1.15 & 1.53 & - \\
\hline & L4 & 93 & 42.2 & 3.8 & 25.8 & $7 \varphi 5 \mathrm{~mm}$ & 467 & 1.07 & 1.51 & - \\
\hline \multirow{4}{*}{$\begin{array}{c}2 \\
f_{c}= \\
36 \mathrm{MPa}\end{array}$} & LF1 & 90 & 35.8 & 3.9 & 23.9 & - & 390 & - & - & 1.00 \\
\hline & LF2 & 86 & 36.0 & 3.9 & 24.0 & $3 \varphi 10 \mathrm{~mm}$ & 517 & - & - & 1.33 \\
\hline & LF3 & 91 & 36.2 & 4.0 & 24.2 & $5 \varphi 10 \mathrm{~mm}$ & 541 & - & - & 1.39 \\
\hline & LF4 & 88 & 36.2 & 4.0 & 24.2 & $7 \varphi 5 \mathrm{~mm}$ & 501 & - & - & 1.28 \\
\hline
\end{tabular}

$\mathrm{D}=$ effective slab depth; $\mathrm{f}_{c}=$ concrete compressive strength on testing day; $\mathrm{f}_{\mathrm{t}}=$ tension strength on testing day; $\mathrm{V}_{\mathrm{u}}=$ ultimate load; $\mathrm{E}_{\mathrm{c}}=$ modulus of elasticity for concrete; $\mathrm{V}_{\mathrm{uLi}}=$ ultimate load for slabs with fibers; $\mathrm{V}_{\mathrm{uLi}}=$ ultimate load for slabs without fibers 


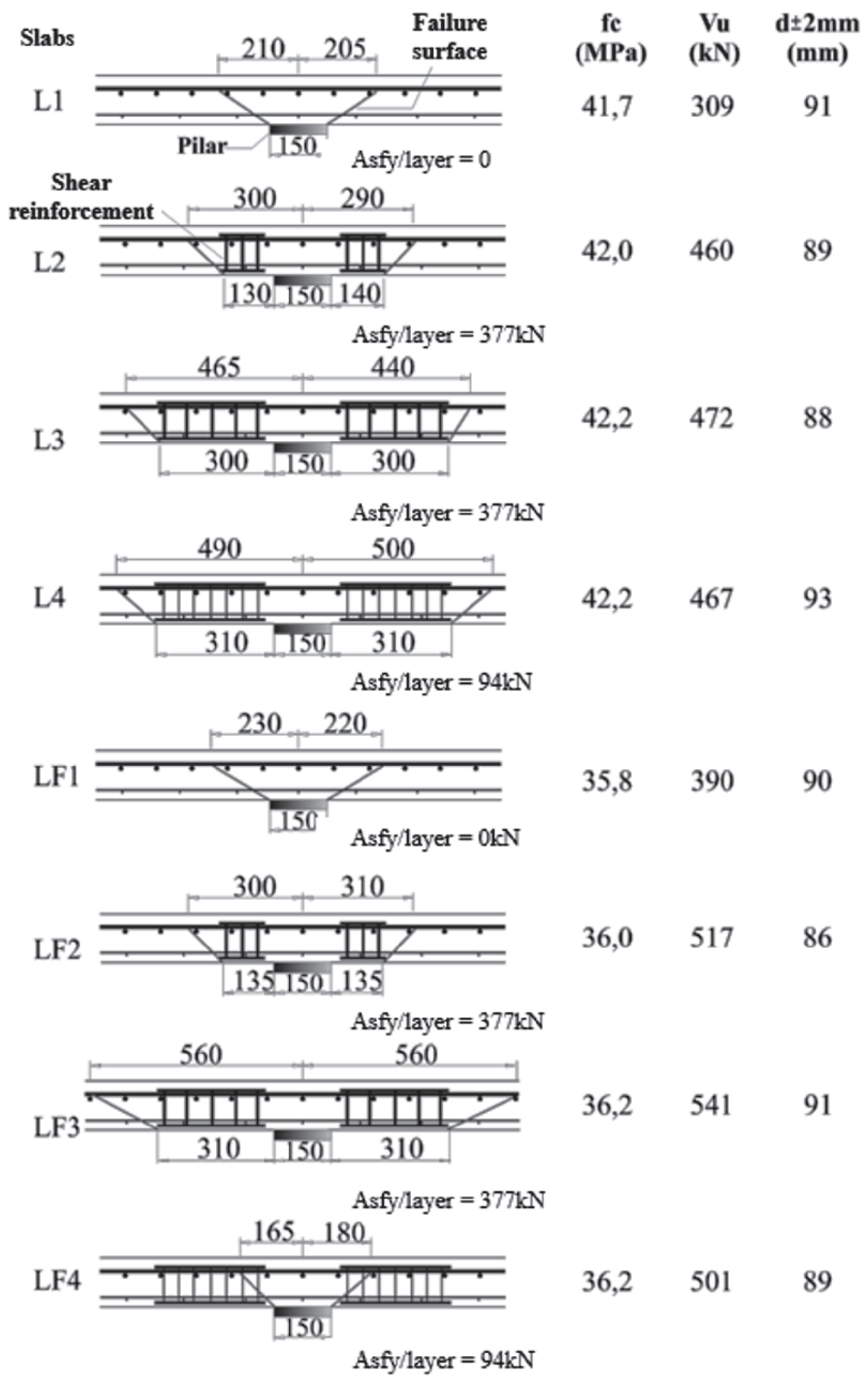

Figure 10

Failure surfaces 


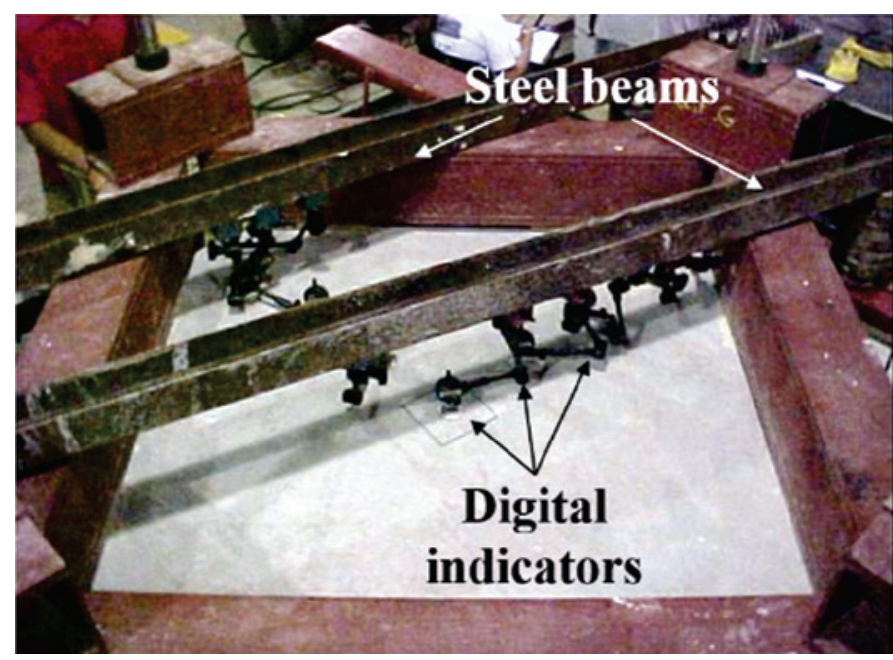

(a) Top view

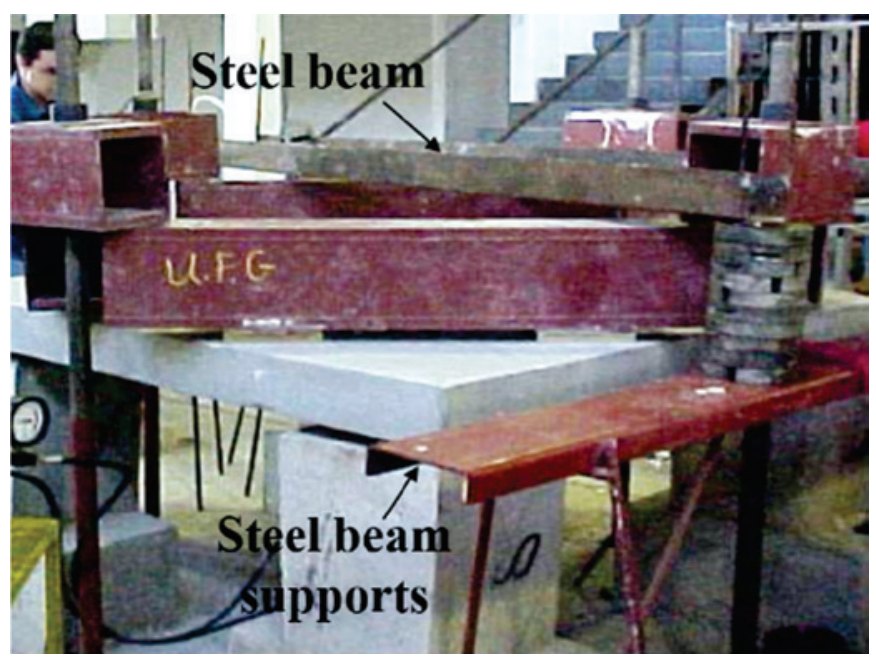

(b) Side view

\section{Figure 11}

Setup of digital indicators for measuring vertical displacements: (a) Top view; (b) Side view

Slabs with fibers had higher ultimate loads than slabs without fibers. Fibers increase punching shear strength about $14 \%$. The largest increase in ultimate load (26\%) occurred in the slab without shear reinforcement (LF1).

\subsection{Vertical slab displacements}

Vertical slab displacements were measured by nine digital displacement indicators located at the slab's edge. Indicators were manufactured by Mitutoyo and had a $0.01 \mathrm{~mm}$ precision and a 14 $\mathrm{mm}$ gauge length. Indicator were mounted on a fixed C-channel steel beam supported on tripods as shown in Figure 11. Indica- tors were placed on the slab's top surface, radially spaced away from the column face as shown in Figure 12. Digital indicators D1 through D9 were used to measure vertical slab displacements with respect to the reaction strong floor.

All slabs presented a symmetrical vertical displacement two-way profile similar to the one shown in Figure 13 for slabs L4 and LF4. Displacements increased with loading and the largest displacements occurred at the slab's center. This was expected due to the nature and symmetry of the loading system.

In general, fibers increased displacements in slabs when comparing slabs with and without fibers. Comparing displacements for slabs L1 and LF1, without shear reinforcement, fibers increased

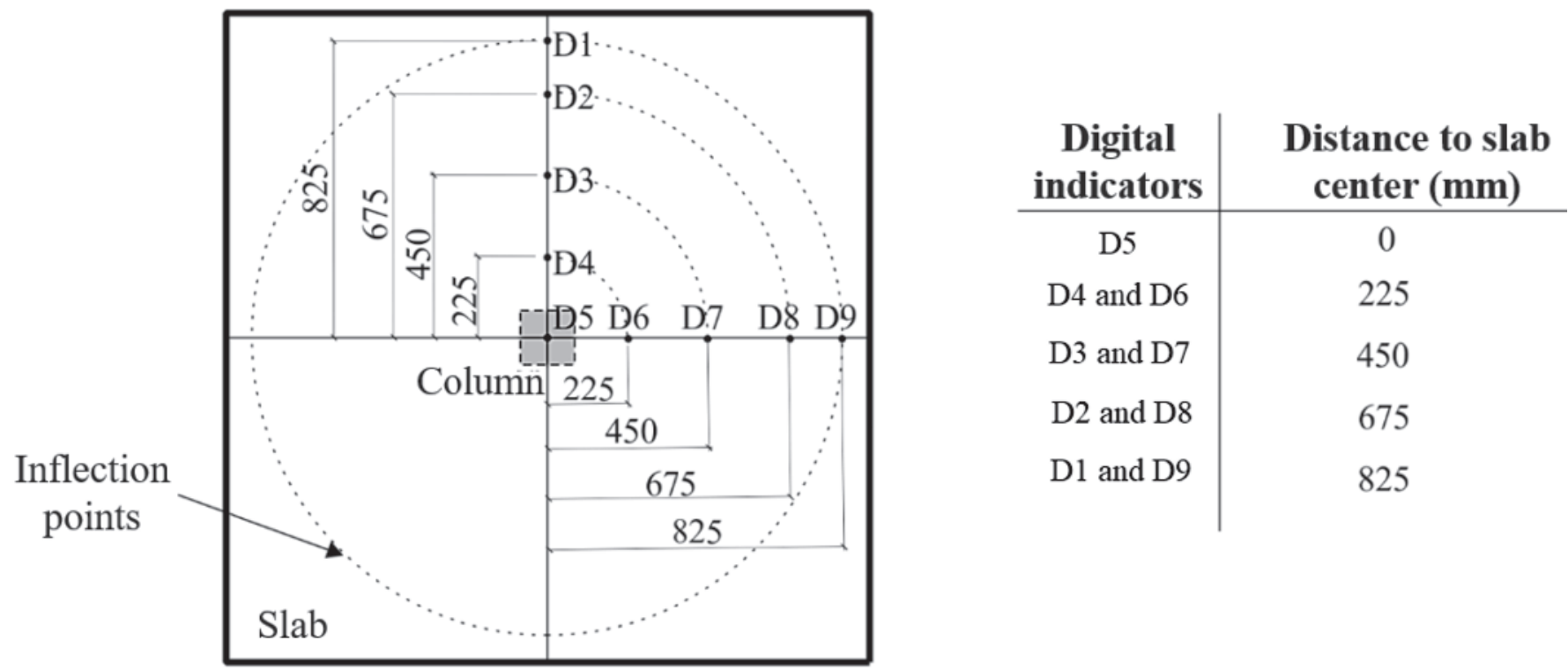

Figure 12

Placement of digital indicatores (units in $\mathrm{mm}$ ) 
Punching shear in concrete reinforced flat slabs with steel fibers and shear reinforcement
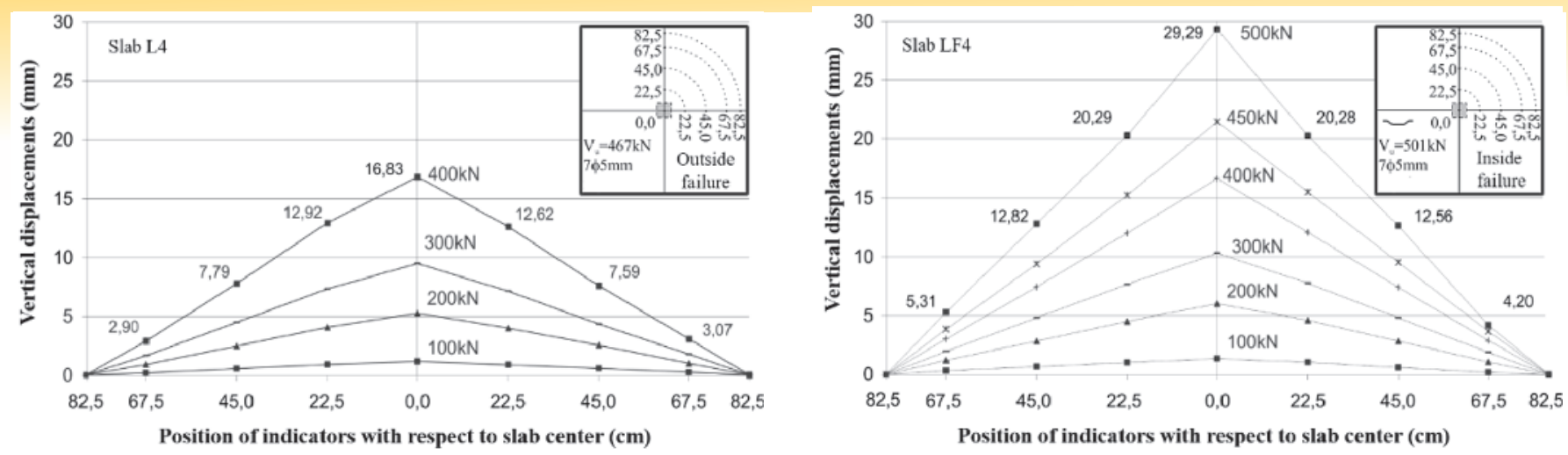

\section{Figure 13}

Vertical displacements vs position of indicators in slabs L4 and LF4

displacements for all loading stages, according to Figure 14. Slab LF2 had smaller displacements than slab L2 up to a load of 250 $\mathrm{kN}$, but the situation reversed after this loading stage when displacements were larger for the slab with fibers. Slab LF3 always had smaller displacements than its counterpart slab LF3 for the same loading stages. Slab LF4 had the highest displacements of all slabs, including its counterpart slab L4.

An increase in the size of the reinforced shear region led to an
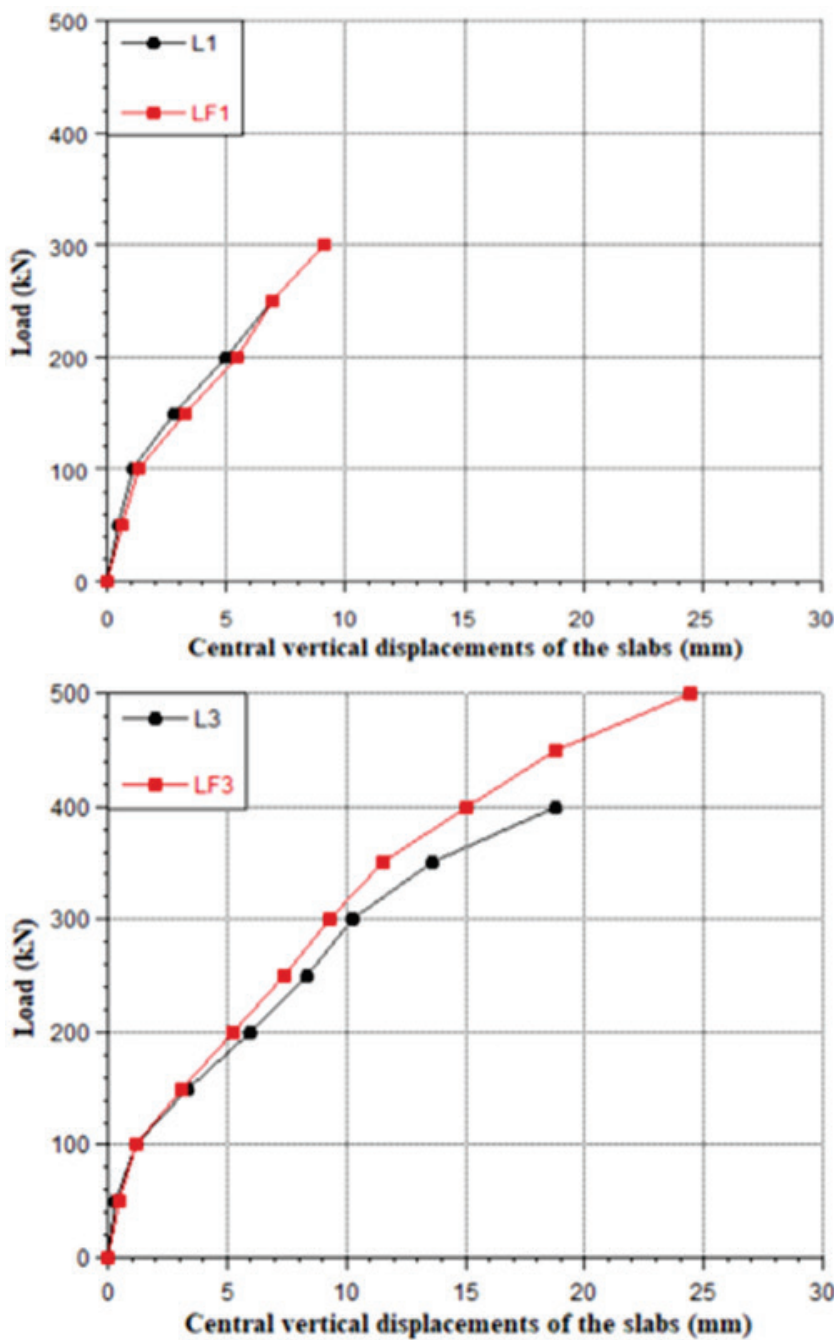

Figure 14

Load vs central vertical displacements of the slabs increase in the slab's center displacement before failure. Slabs L3 and L4 had center displacements higher than slabs L1 and $\mathrm{L} 2$ at the same loading stage. At loading stage of $400 \mathrm{kN}$, the largest center displacement was $18.66 \mathrm{~mm}$ for slab $\mathrm{L} 3$, which is $10 \%$ greater than the center displacement of slab L4 and $19 \%$ more than the center displacement of slab L2. This shows that using a smaller number of shear studs and a smaller diameter stud influenced vertical displacements more than ultimate load.
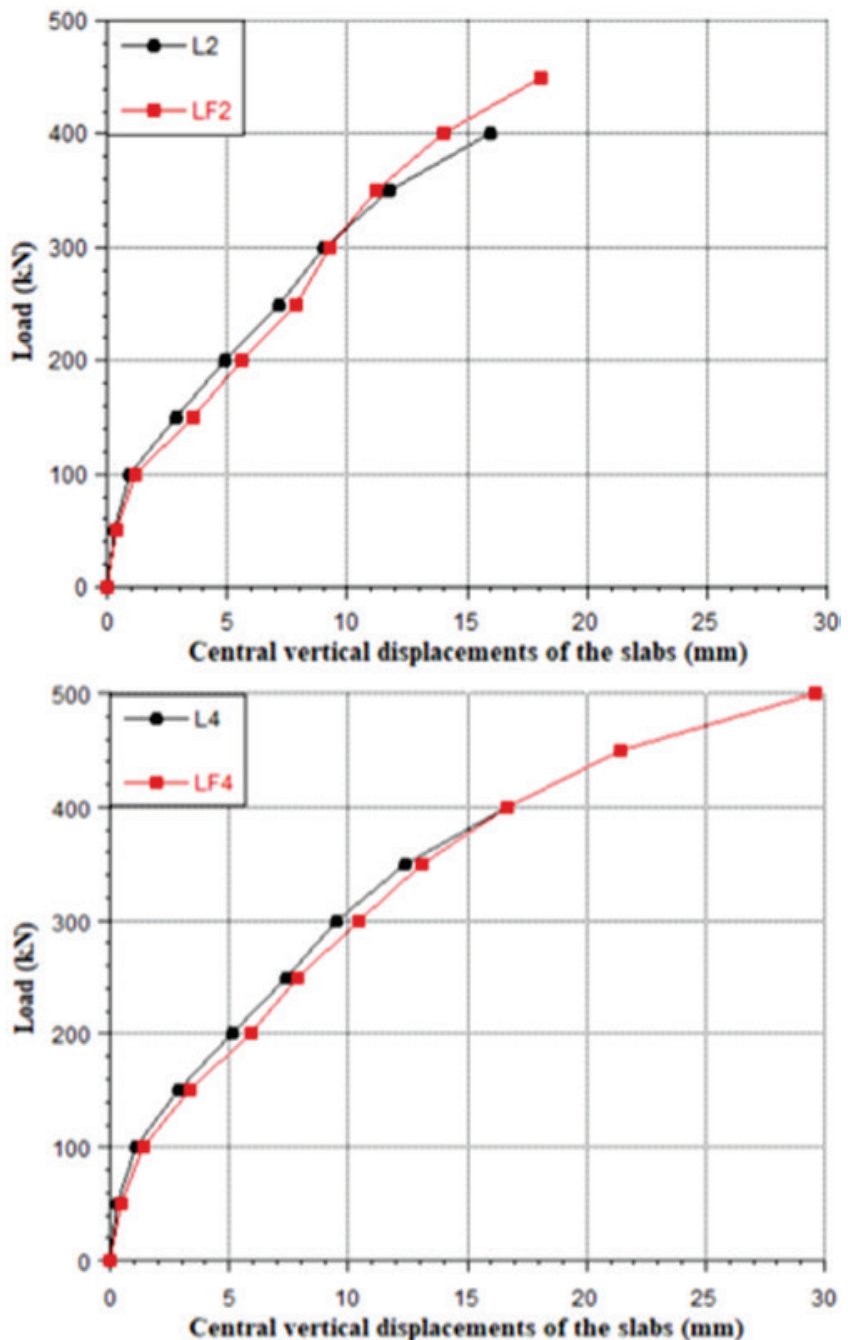


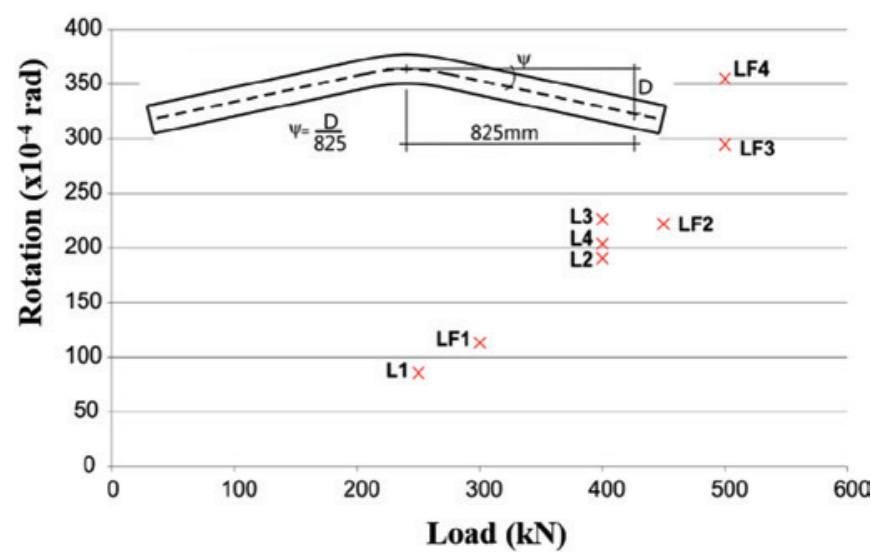

\section{Figure 15}

Slab rotations at ultimate loads

Difference in ultimate loads of slabs L3 and L4 is only $1 \%$.

From Figure 14, the fibers increased the tenacity of the slabs by at least $21 \%$ (slab LF2 compared to L2) and by up to $114 \%$ (slab LF4 compared to L4). In the slab without shear reinforcement (LF1), this increase was $50 \%$.

Slab rotation was calculated based on central vertical displacements and are plotted as a function of ultimate load in Figure 15. Rotations at ultimate loads were always higher for slabs with fibers when compared to their counterparts without fibers. But similar rotations at ultimate loads can occur depending on the shear reinforcement used, as shown for slabs L3 and LF2.

\subsection{Cracking patterns}

Cracking appeared on the slab's top surface and the slabs had similar cracking patterns. Radial cracking appeared first in all slabs, around the column, and propagated away from the column as loading increased. Figure 16 shows the cracking pattern of all slabs at higher loading stages (from $75 \%$ to $90 \%$ of the ultimate load).

Table 4 shows radial cracking loads $V_{r}$ and displacements $\delta_{r}$ at the slab's center at the radial cracking load and comparisons of these values with ultimate loads $V_{u}$ and displacements $\delta_{u}$ at ultimate loads for all slabs. Comparisons were made by calculating ratios $V_{r} / V_{u}$ and $\delta_{r} / \delta_{u}$. Displacements at cracking loads for slabs without shear reinforcement were $13.2 \%$ (for slab L1) and $11.7 \%$ (for slab LF1) of the displacements at ultimate loads. For the other slabs, the ratio $\delta_{r} / \delta_{u}$ ranged from $4.7 \%$ to $6.8 \%$ independently of the presence of fibers. This is due to a constant cracking load of $100 \mathrm{kN}$ for all slabs, except for slab L4 which cracked at $75 \mathrm{kN}$.

Slabs without shear reinforcement also had the highest $\mathrm{V}_{\mathrm{r}} / \mathrm{V}_{\mathrm{u}}$ ratios at $32.4 \%$ for slab L1 and $25.6 \%$ for slab LF1. For all other slabs the $\mathrm{V}_{r} / \mathrm{V}_{\mathrm{u}}$ ratios ranged from $16.1 \%$ to $21.7 \%$. This is a similar behavior as when the displacement ratios $\delta_{\mathrm{r}} / \delta_{\mathrm{u}}$ were compared.

Table 5 shows circumferential cracking loads $V_{c}$ and displacements $\delta_{c}$ at the slab's center at the circumferential cracking load and comparisons of these values with ultimate loads $V_{u}$ and displacements $\delta_{u}$ at ultimate loads for all slabs. Comparisons were made by calculating ratios $\mathrm{V}_{c} / \mathrm{V}_{\mathrm{u}}$ and $\delta_{\mathrm{c}} / \delta_{\mathrm{u}}$.

Circumferential cracking always appeared after radial cracking and higher loads $V_{c}$ were expected. Slabs with fibers had lower

\section{Table 4}

Comparisons of radial cracking loads and displacements at cracking loads

\begin{tabular}{|c|c|c|c|c|c|c|c|}
\hline Group & Slab & $\mathrm{V}_{\mathrm{u}}(\mathrm{kN})$ & $V_{r}(k N)$ & $\delta_{\mathrm{r}}(\mathrm{mm})$ & $\delta_{\mathrm{u}}(\mathrm{mm})$ & $\delta_{\mathrm{r}} / \delta_{\mathrm{u}}(\%)$ & $\mathrm{V}_{\mathrm{r}} / \mathrm{V}_{\mathrm{u}}(\%)$ \\
\hline \multirow{4}{*}{1} & L1 & 309 & 100 & 0.93 & 7.05 & 13.2 & 32.4 \\
\hline & $\mathrm{L} 2$ & 460 & 100 & 0.98 & 15.73 & 6.2 & 21.7 \\
\hline & L3 & 472 & 100 & 1.23 & 18.66 & 6.6 & 21.2 \\
\hline & L4 & 467 & 75 & 1.15 & 16.83 & 6.8 & 16.1 \\
\hline \multirow{4}{*}{2} & LF1 & 390 & 100 & 1.27 & 10.85 & 11.7 & 25.6 \\
\hline & LF2 & 517 & 100 & 1.22 & 18.31 & 6.7 & 19.3 \\
\hline & LF3 & 541 & 100 & 1.22 & 24.32 & 5.0 & 18.5 \\
\hline & LF4 & 501 & 100 & 1.38 & 29.29 & 4.7 & 20.0 \\
\hline
\end{tabular}

$V_{r}=$ Cracking load at the first visual radial crack; $V_{u}=$ Ultimate load; $\delta_{r}=$ Central vertical displacement at cracking load; $\delta_{u}=$ Central vertical displacement at ultimate load

\section{Table 5}

Comparisons of circumferential cracking loads and displacements at cracking loads

\begin{tabular}{|c|c|c|c|c|c|c|c|}
\hline Group & Slab & $\mathrm{V}_{\mathrm{u}}(\mathrm{kN})$ & $\mathrm{V}_{\mathrm{c}}(\mathrm{kN})$ & $\delta_{c}(\mathrm{~mm})$ & $\delta_{\mathrm{u}}(\mathrm{mm})$ & $\delta_{\mathrm{c}} / \delta_{\mathrm{u}}(\%)$ & $\mathrm{V}_{\mathrm{c}} / \mathrm{V}_{\mathrm{u}}(\%)$ \\
\hline \multirow{4}{*}{1} & L1 & 309 & 175 & 3.90 & 7.05 & 55.3 & 56.6 \\
\hline & $\mathrm{L} 2$ & 460 & 200 & 4.92 & 15.73 & 31.3 & 43.5 \\
\hline & L3 & 472 & 200 & 5.99 & 18.66 & 32.1 & 42.4 \\
\hline & L4 & 467 & 150 & 3.04 & 16.83 & 18.1 & 32.1 \\
\hline \multirow{4}{*}{2} & LF1 & 390 & 125 & 2.22 & 10.85 & 20.5 & 32.1 \\
\hline & LF2 & 517 & 150 & 3.46 & 18.31 & 18.9 & 29.0 \\
\hline & LF3 & 541 & 150 & 3.24 & 24.32 & 13.3 & 27.7 \\
\hline & LF4 & 501 & 100 & 1.38 & 29.29 & 4.7 & 20.0 \\
\hline
\end{tabular}



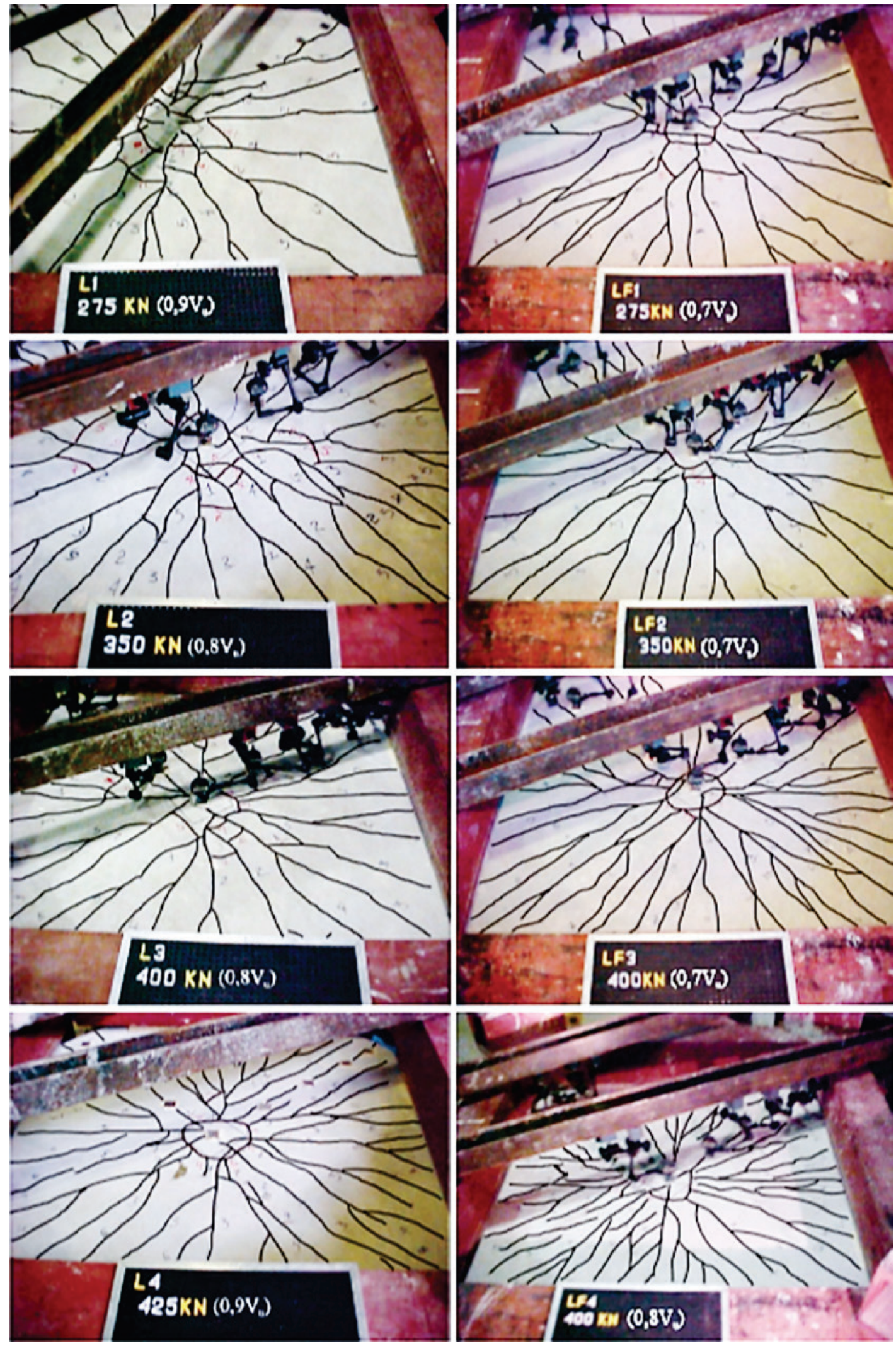

Figure 16

Slab cracking patterns at higher loading stages (70\% to $90 \%$ of ultimate loads) 
circumferential cracking loads than slabs without fibers (average of $27 \%$ lower). Displacement ratios $\delta_{c} / \delta_{u}$ and load ratios $V_{c} l$ $V_{u}$ were always smaller (about $50 \%$ smaller) for slabs with fibers when compared to their counterparts without fibers. These ratios were higher for slabs without shear reinforcement. Slab LF4 had the largest central displacement and both radial and circumferential cracking occur first when compared to the other slabs (lowest ratios).

During testing, cracks in slabs with fibers had smaller thicknesses when observed visually. Slabs LF3 and LF4 had more thin cracks propagating from main radial cracks. These two slabs had shear reinforcement and concrete with fibers.

\section{Conclusions}

The main variables in this study were the use of steel fibers in the concrete and use of shear stud reinforcement. The shear reinforcement had 3, 5 or 7 layers of studs with stud diameters of $5 \mathrm{~mm}$ or $10 \mathrm{~mm}$ and spacing was $43 \mathrm{~mm}$ or $63 \mathrm{~mm}$. Based on the results and within the limitations of these tests, the most important conclusions are:

a) Ultimate loads increased due to use of shear reinforcement and fibers. The ultimate load of slab LF3 (with fibers and shear studs) increase $75 \%$ when compared to the ultimate load of slab L1 (without shear reinforcement or fibers);

b) The use of fibers increased ultimate loads by $26 \%$ for the slab without shear reinforcement (slab LF1) and increased approximately $12 \%$ for the slabs with shear reinforcement (slabs LF2, LF3 and LF4);

c) Fibers change the mode of failure of slabs L4 and LF4 from outside to inside the shear reinforcement region. This type of failure presented the largest vertical displacements;

d) Vertical displacements were higher in slabs with fibers up to $74 \%$ when compared to their counterparts without fibers;

e) Radial cracking appeared at practically the same loading stage in all slabs independently of shear reinforcement and use of fibers in concrete. The slabs with fibers had a higher number of radial cracks with smaller thicknesses.

\section{Acknowledgements}

The authors wish to thank the invaluable financial support of CAPES-Coordenação de Aperfeiçoamento de Pessoal de Nível Superior.

\section{References}

[1] ALBUQUeRQUE, E. J. P. Punching in flat slabs with shear reinforcement and rectangular interior columns (in Portuguese). 2010. 299 p. Dissertation (MSc. Thesis in Civil Engineering) - University of Brasília. Brasília, DF, 2010.

[2] ASSOCIAÇÃO BRASILEIRA DE NORMAS TÉCNICAS. ABNT NBR6118: Projeto de Estruturas de Concreto Armado. Rio de Janeiro, 2014.

[3] BORGES L.L.J, MELO G.S.; GOMES R.B., Punching shear of reinforced concrete flat plates with openings. ACI Structural Journal, v. 110, v. 4, July-Aug. 2013; p. 1-10.
[4] CHENG, M.-Y.; PARRA-MONTESINOS, G. J. Evaluation of steel fiber reinforcement for punching shear resistance in slab-column connections- Part I: Monotonically increased load. ACl Structural Journal. v.107, n.1, Jan-Feb. 2010; p. 101-109.

[5] Choi, K-K.; Taha, M.M.R.; Park, H-G.; Maji, A.K. Punching shear strength of interior concrete slabcolumn connections reinforced with steel fibers. Cement \& Concrete Composites, v. 29, 2007; p. 409-420.

[6] FIGUEIREDO, A. D. Fiber reinforced concrete. 2011. $256 \mathrm{f}$. Livre Docência - Escola Politécnica of the University of São Paulo, São Paulo, SP, 2011.

[7] GOMES, R. B.; REGAN, P. E.; Punching resistance of RC flat slab with shear reinforcement. Journal of Structural Engineering, vol.125, 1999; p. 684-692.

[8] GOUVEIA, N.; FERNANDES, N. A. G.; FARIA, D. M. V.; RAMOS, A. M. P.; LÚCIO, V. J. G. SFRC Flat Slabs Punching Behaviour - Experimental Research. Composites: Part B. v.63, 2014; p. 161-171.

[9] HANAI, J. B.; HOLANDA, K. M. A. Similarities between punching and shear strength of steel fiber reinforced concrete (SFRC) slabs and beams. Revista Ibracon de Estruturas e Materiais. v.1, n.1, p. 1-16, mar. 2008.

[10] LIMA NETO, A.F. Punhcing shear in reinforce concrete flat plates with drop panels (in Portuguese). 2012. 189 p. Thesis (D.Sc. in Structures and Construction) - University of Brasília, Brasília, DF, 2012.

[11] MAGHSOUDI, A.A.; SHARIFI, Y. Ductility of high strength concrete heavily steel reinforced members. Scientia Iranica, v. 16, n. 4, 2009; p. 297-307.

[12] MAYA, L. F.; RUIZ, M. F.; MUTTONI, A.; FOSTER, S.J. Punching shear strength of steel fiber reinforced concrete slabs. Engineering Structures, v.40, feb. 2012; p. 83-94.

[13] MORAES NETO, B. N.; BARROS, J. A. O.; MELO, G. S. S. A. A model for the prediction of the punching resistance of steel fibre reinforced concrete slabs centrically loaded. Construction and Building Materials, v. 46, 2013; p. 211-223.

[14] NGUYEN-MINH, L.; ROVŇÁK, M.; TRAN-QUOC, T.; NGUYENKIM, K. Punching shear resistance of steel fiber reinforced concrete flat slabs. Procedia Engineering, v. 14, 2011; 1830-1837.

[15] SILVA, J. A.; MARQUES, M. G.; TRAUTWEIN, L. M.; GOMES, R. B.; GUIMARÃES, G. N. Punching of reinforced concrete flat slabs with holes and shear reinforcement. REM - International Engineering Journal, v. 70, p. 407-413, 2017.

[16] TRAUTWEIN, L. M.; BITTENCOURT, T. N.; GOMES, R. B.; BELLA, J. C D. Punching strength of flat slabs with unbraced shear reinforcement. ACI Structural Journal, v. 108, n. 2, Mar-Apr. 2011; p. 197-205. 